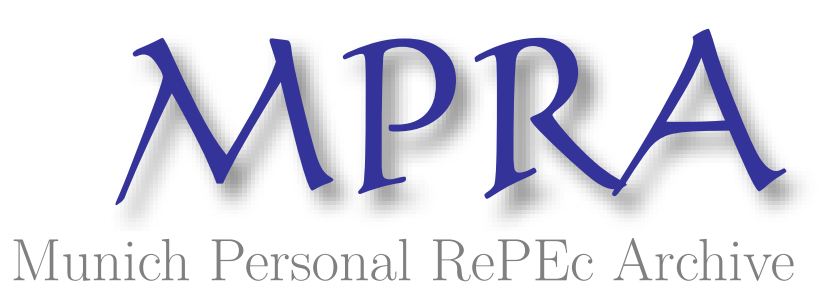

Japanese and Korean Automobile
Exports and the Alchian-Allen Theorem

Resiandini, Pramesti

July 2012

Online at https://mpra.ub.uni-muenchen.de/41928/

MPRA Paper No. 41928, posted 16 Oct 2012 08:46 UTC 


\title{
Japanese and Korean Automobile Exports and the Alchian-Allen Theorem
}

July 2012

Pramesti Resiandini

\begin{abstract}
$\underline{\text { Abstract }}$
This paper compares data on Japanese and Korean automobile exports to the United States to examine consistency with the Alchian-Allen theorem. The theorem suggests that imposing a per unit charge such as transport cost will lower the relative price and increase the relative consumption of higher quality cars. Results show that the relative price of higher-quality cars is not necessarily lower with increased shipping costs, measured by CIF charges (cost, insurance, and freight). A possible explanation is that insurance and other shipping charges are imposed based on the car price, and these charges reduce or eliminate the Alchian-Allen effect of per-unit freight charge.
\end{abstract}

Keyword: International Trade; Transport Costs; Alchian-Allen Theorem; Dynamic OLS JEL classification: F14

Corresponding address: Department of Economics, Andrew Young School of Policy Studies, Georgia State University, Atlanta, GA 30303. Tel: 1-404-413-0153. Fax: 1-404-413-0145. Email: presiandini@gsu.edu.

Acknowledgements: I thank Henry Thompson, James Barth, Hyeongwoo Kim, Daniel Gropper, Jennings Byrd, and Thomas Doran for helpful comments. 


\section{Introduction}

The Alchian-Allen theorem (1964) is often called "shipping the good apples out"

theorem. It proposes that a per-unit charge will lower the relative price and increase the relative consumption of the higher quality good (e.g., Hummels and Skiba [2002] and Bauman [2004]). The theorem originally applied to a two-good world, but Borcherding and Silberberg (1978) provide a proof of its application with two goods in a many-good world given the two goods are close substitutes. Bauman (2004) relaxes the assumption of close substitutability between the two goods in a many-good world, broadening the scope of the theorem.

A recent application of "shipping the good apples out" in international trade is reported by Hummels and Skiba (2002, 2004), who provide theoretical and empirical evidence based on bilateral trade data for six countries. With data on traded good prices, quantities, and shipping costs, they point out that shipping costs behave like a quantitative restriction similar to quotas (2002, p. 4). Another important contribution is their analysis of variation in ad-valorem trade costs such as tariffs, suggesting that they lower the relative demand for high quality goods and reduce the Alchian-Allen effect.

The present paper analyzes Japanese and Korean automobile exports to the United States based on monthly data for the period 1995 to 2005 to examine consistency with the AlchianAllen theorem. The U.S. automobile market is selected because it is the largest automobile market in the world during the period. Automobile trade, in general, is an interesting area for testing the Alchian-Allen effect of transport cost. Automobiles are considered large goods, and this paper presumes that transport cost matters in automobile trade.

Japan and Korea are selected as the exporting countries for the following reasons: (1) Japan has historically been the largest automobile exporter to the United States with a share of 
about $50 \%$ to $70 \%$ of U.S. automobile imports during the period, (2) Korea has become one of the major automobile exporters to the U.S. with a share of over $13 \%$ of U.S. imports at the end of the period of observation, ${ }^{1}$ and (3) the two exporting countries are located similar distance from the U.S.

One implication of the Alchian-Allen theorem may be in the choice of production location as Japanese and (more recently) Korean major automakers own production plants in the U.S. Issues on automobile trade between Japan and the United States have been on the political agenda of the two countries for decades. A trade dispute occurred from 1993 to 1995 following the unintended results of Japan's voluntary export restraint (VER) system that led to increased competition in the U.S. luxurious automobile market. An agreement ended the two-year dispute after Japan agreed to deregulate its domestic automobile market. Another important deal reached in 1995 was that Japanese automakers in the U.S. would increase production by $25 \%$ to 2.65 million automobiles in 1998 (Katzner and Nikomarov, 2008).

The present study utilizes the dynamic OLS (DOLS) method of Stock and Watson (1993) to estimate car imports from Japan and Korea with car price, shipping costs, and the U.S. dollar exchange rate as explanatory variables. Trade costs generally include tariffs and shipping costs. Shipping costs include freight, insurance, and other charges. In the case of U.S. car imports, the tariff rate does not vary over the period of observations (1995-2005), and it is the same for both countries of origin. ${ }^{2}$ Therefore, the trade costs in this study include only shipping costs.

\footnotetext{
${ }^{1}$ Import shares are calculated with import quantity data from the United States International Trade Commission (USITC) available on the USITC Dataweb, http://dataweb.usitc.gov/.

${ }^{2}$ Tariff rate for small size cars (HTS 8703.22) and medium size cars (HTS 8703.23) is $2.5 \%$ of the customs value. The rate is computed based on data on calculated duties and customs value available on the USITC Dataweb, http://dataweb.usitc.gov/.
} 
Moreover, the model does not include a distance variable, which is commonly used in the studies of bilateral trade, because Japan and Korea are located similar distance from the United States.

The main hypothesis tested in this paper is that as shipping costs increase, U.S. imports of higher-quality cars from Japan and Korea increase. Higher- and lower-quality cars are first determined by comparing the prices of cars in the same car category. Freight charge, the main component of shipping costs, is utilized in the model as an increasing function of the price of oil with a one-month lag. ${ }^{3}$ The actual shipping costs include other charges such as insurance and handling. The inference is that freight charge measures per-unit shipping cost, whereas insurance and other charges may vary with car prices. Consistent with Hummels and Skiba (2002) regarding ad-valorem charges, the present paper proposes that higher insurance and other charges reduce or eliminate the Alchian-Allen effect on the demand for higher quality cars.

The U.S. dollar nominal exchange rate is utilized in the present model. ${ }^{4}$ Given general conditions of currency supply and demand, an appreciation of the dollar is expected to lower the price of foreign goods, whereas a depreciation of the dollar is expected to raise the price of foreign goods in the U.S. market. A study of exchange rate pass-through in the U.S. automobile market by Banik and Biswas (2007) finds that price competition among firms determines the degree of exchange rate pass-through. They point out that the degree of exchange rate passthrough for the Japanese and Korean automobile exporters is low, which indicates their attempt to protect their market share in the U.S. by offsetting the effect of exchange rate fluctuations on car prices.

\footnotetext{
${ }^{3}$ This variable is constructed based on an observation that the price of oil positively affects shipping rates with a one-month lag (Kilian, 2009).

${ }^{4}$ An indicator variable for the Asian financial crisis of 1997-1998 controls for the large depreciation of the Korean won against the dollar.
} 
This paper argues that the Alchian-Allen theorem holds when shipping costs account for per-unit freight charge only without considering insurance and other charges that may be imposed based on the car price. With insurance and other charges, the Alchian-Allen theorem may hold when the effect of per-unit charge is larger than the effect of the ad-valorem charges. Present estimates based on Baltic Dry shipping index as a measure of freight rate support the Alchian-Allen theorem. Estimations based on actual shipping cost data, however, indicate that the effect of insurance and other charges outweighs the effect of per-unit freight charge. ${ }^{5}$ This result suggests that actual shipping cost data do not support the Alchian-Allen theorem.

Furthermore, this study suggests that foreign car production will be done domestically in the U.S. when trade costs are high, regardless differences in car quality.

The remainder of the paper proceeds as follows. Section 2 discusses the data. Section 3 describes the shipping model and the empirical method. Section 4 discusses the empirical results. Section 5 concludes the paper.

\section{Data}

A time-series model is applied to monthly data of U.S. car imports from Japan and Korea to test consistency with the Alchian-Allen theorem. Four data sets are constructed for the period 1995 to 2005 with 132 observations in each. The four data sets represent higher and lower

${ }^{5}$ Actual shipping cost is calculated by deducting the customs value from the CIF (cost, insurance, and freight) value, and the result is divided by the quantity of car imports. The customs value is defined by the USITC as "the price actually paid or payable for merchandise, excluding U.S. import duties, freight, insurance, and other charges." The CIF value excludes U.S. import duties. The data on customs value, CIF value, and import quantity are available on the USITC Dataweb, http://dataweb.usitc.gov/. 
quality cars from the two exporting countries. Two types of automobiles are examined: small and medium size cars. In this paper, small size cars refer to passenger motor vehicles with engine sizes exceeding 1,000 cc but not exceeding 1,500 cc (HTS 8703.22) and medium size cars refer to passenger motor vehicles with engine sizes exceeding 1,500 cc but not exceeding 3,000 cc (HTS 8703.23).

The data on car imports (in quantities and values) are from the Interactive Tariff and Trade Database of the United States International Trade Commission (USITC) Dataweb. The dollar exchange rates are based on noon buying rates reported by the Federal Reserve Bank of New York. The shipping index used is the Baltic Dry Index from the FactSet Research Systems database. The data on crude oil price is the WTI spot price FOB from the Energy Information Administration of the U.S. Department of Energy. All prices are deflated using Consumer Price Index reported by the Bureau of Labor Statistics.

The relative quality of each import category is determined by comparing its average price relative to those of other import categories as shown in Table 1. Average car prices are calculated based on the U.S. customs value, which is the price actually paid or payable for merchandise, excluding U.S. import duties, freight, insurance, and other charges (USITC, 2010). The average prices of the four import categories can be compared as follows. The cars $c_{s j}$ have a higher price than $c_{s k}$, but the cars $c_{m j}$ has a lower price than $c_{m k}$.

The present study assumes similar product variations in $c_{s j}$ and $c_{s k}$, and applies the same assumption to $c_{m j}$ and $c_{m k}$. Based on the comparison of car prices in Table 1, the relative quality of each import category can be determined: higher quality goods are small size cars from Japan and medium size cars from Korea, and lower quality goods are medium size cars from 
Japan and small size cars from Korea. To be clear, higher quality cars are marked as $c_{s j}^{h}$ and $c_{m k}^{h}$, and lower quality cars are marked as $c_{s k}^{l}$ and $c_{m j}^{l}$.

[Table 1 here]

\section{The shipping model}

The model describes a world with n goods, $c_{s j}^{h}, c_{s k}^{l}, c_{m j}^{l}$, and $c_{m k}^{h}$, and $y$, where $y$ is a composite of "other" goods. The first and second goods are small cars with different qualities, higher and lower. The third and fourth goods are medium cars with higher quality and lower quality. Higher quality cars are represented by $c_{h}$ and lower quality cars are represented by $c_{l}$; then by assumption, the car prices follow $p_{h}>p_{l}>0$.

A per-unit shipping cost (freight charge), $f$, is added to the prices of $c_{h}$ and $c_{l}$. The prices become $p_{h}+f, p_{l}+f$, and $p_{y}$, respectively.

Following Borcherding and Silberberg (1978),

$$
\partial\left(c_{h} / c_{l}\right) / \partial f>0
$$

where $c_{h}\left(p_{h}, p_{l}, p_{y}, U\right)$ and $c_{l}\left(p_{h}, p_{l}, p_{y}, U\right)$ are Hicksian demand functions. As the shipping cost rises, the consumption of higher quality cars increases relative to the lower quality cars, holding real income and the prices of all other goods constant.

Given $\varepsilon_{i j}=\left(p_{j} / c_{i}\right)\left(\partial c_{i} / \partial p_{j}\right)$ be the compensated elasticities, applying the chain rule and quotient rule on (2) will result in

$$
\partial\left(c_{h} / c_{l}\right) / \partial f=\frac{c_{h}}{c_{l}}\left[\left(\varepsilon_{h h} / p_{h}\right)+\left(\varepsilon_{h l} / p_{l}\right)-\left(\varepsilon_{l h} / p_{h}\right)-\left(\varepsilon_{l l} / p_{l}\right)\right]>0
$$


which confirms the Alchian-Allen theorem.

In a two-good world, Borcherding and Silberberg (1978) note that Hick's third law (1946) applies $\left(\sum_{i} \varepsilon_{i j}=0\right)$. This implies that, in a two-car world, the two cars must be substitutes $\left(\varepsilon_{h l}>0\right)$ and own-price elasticities are negative $\left(\varepsilon_{l l}<0\right)$, which can be obtained by substituting for $\varepsilon_{h h}$ and $\varepsilon_{l h}$ (given $\varepsilon_{h l}=-\varepsilon_{l h}$ ). In an $n$-good world (introducing a third, composite of "other" goods), Borcherding and Silberberg show that Alchian-Allen holds if the two goods are assumed to be close substitutes.

Bauman (2004) relaxes the assumption of close substitutability between the two goods in an $n$-good world. So long as the two goods are not close complements $\left(\varepsilon_{h l}>\varepsilon_{l l}\right)$ and are not close in price $\left(p_{h}>>p_{l}\right)$ a per-unit charge will increase the relative consumption of the higher quality good (2004, p.535). The implication is that the higher quality cars from Japan $\left(c_{s j}^{h}\right)$ can be substitute to lower quality cars from Japan $\left(c_{m j}^{l}\right)$ or lower quality cars from Korea $\left(c_{s k}^{l}\right)$. They do not have to be close substitutes. When per-unit shipping costs increase, U.S. demand for higher quality cars from Japan increases relative to lower quality cars from both Japan and Korea.

The price of cars depends on the U.S. customer price $\left(p_{x i}\right)$ and trade costs. Trade costs include tariffs and shipping costs; and shipping costs include freight, insurance, and other charges. As previously discussed, the trade costs include only shipping costs $(z)$ because tariff does not vary during the period of observations.

Let $f$ denotes freight rate and $g$ denotes ad-valorem insurance and other shipping charges, then the price of car at destination follows

$$
p_{x i}^{U S}=f+g_{x i} p_{x i}
$$


where $g>1$.

Freight rate $f$ represents a per-unit cost that follows the Alchian-Allen theorem, assumed the same for Japan and Korea given similar distance to the United States; and $g$ is ad-valorem charges that increase with car price, $g=F(p)$. The ad-valorem charges $g$ are taken into account when the model utilizes the actual CIF (cost, insurance, and freight) charges instead of freight rate. The actual shipping cost data are calculated based on the U.S. customs value and CIF value of car imports as well as import quantity reported by the USITC. The USITC data do not allow for decomposing the CIF charges into cost, insurance, and freight separately. Hence, another data set is constructed using Baltic Dry Index to measure the effect of freight rate in the absence of insurance and other charges. To summarize, shipping costs are measured in two ways: (1) using Baltic Dry Index as an increasing function of oil price, and (2) using the actual CIF charges.

The consumer utility is based on Hummels and Skiba (2002) and applied specifically to the utility obtained by the U.S. consumer from buying imported cars. The U.S. consumer obtains greater utility from higher quality cars,

$$
U_{x}=\left[\sum_{x, i}\left\{\lambda_{x i}^{l}\left(c_{x i}^{l}\right)^{\theta}+\lambda_{x i}^{h}\left(c_{x i}^{h}\right)^{\theta}\right\}\right]^{1 / \theta}
$$

denoting $c$ as car quantity and $\lambda$ as car quality, where $\lambda_{x i}^{h}>\lambda_{x i}^{l}$ and $\theta=1-\frac{1}{\sigma}$, and $\sigma$ is the elasticity of substitution between higher and lower quality cars based on the CES utility function. Subscript $x$ denotes small car $(s)$ or medium car $(m)$, and subscript $i$ denotes exporting country, Japan $(j)$ or Korea $(k)$. 
An expenditure minimization problem for US consumer buying imported cars can be constructed with the car price in (3) and consumer utility in (4). Assuming competitive firms, the consumer's first order conditions implies

$$
\frac{c_{x i}^{h}}{c_{x i}^{l}}=\left(\frac{p_{x i}^{l} g_{x i}+f}{p_{x i}^{h} g_{x i}+f}\right)^{\sigma}\left(\frac{\lambda_{x i}^{h}}{\lambda_{x i}^{l}}\right)^{\sigma}
$$

The results of further derivations of (5) with respect to $f$ and $g$ suggest that the relative consumption of higher quality cars increases with shipping costs when the effect of per-unit freight charge is larger than the effect of ad-valorem insurance and other charges. As previously discussed, Hummels and Skiba (2002) argue that ad-valorem charges reduce the Alchian-Allen effect on shipping cost. Consequently, Alchian-Allen theorem is expected to hold when shipping costs do not count for ad-valorem charges, or when the effect of per-unit charge is larger than that of ad-valorem charges.

The shipping model estimates the quantity of U.S. car imports from Japan and Korea with three main explanatory variables: car price, shipping costs, and the exchange rate. All variables in the model are in natural log form.

$$
c_{x i}=F\left(p_{x i}, z_{x i}, e_{i}\right)
$$

where subscript $x$ denotes small car $(s)$ or medium car $(m)$, and subscript $i$ denotes exporting country, Japan $(j)$ or Korea $(k)$. The variables are defined as follows:

$c=$ quantity of car imports

$p=$ car price per unit based on the U.S. customs value (excluding shipping costs)

$Z=$ shipping costs, measured in two ways: 
(a) using freight rate $(f)$, constructed with Baltic Dry Index as an increasing function of oil price (o), where $f=F\left(o_{t-1}\right)$.

(b) using actual shipping costs $\left(t_{x i}\right)$, based on CIF charges.

$e=$ dollar exchange rate (USD/JPY or USD/KRW) with an indicator variable controlling for the Asian financial crisis in the case of KRW.

The model is estimated using the dynamic OLS (DOLS) regression proposed by Stock and Watson (1993). The advantage of using DOLS is that it estimates long-run equilibria in cointegrated systems that may have variables integrated with different orders. The DOLS estimates parameter $\beta$ of the following regression:

$$
y_{1 t}=\beta^{\prime} y_{2 t}+d(L) \Delta y_{2 t}+v_{t}
$$

where $d(L)$ is the leads and lags of $\Delta y_{2 t}$, the first differences of any $I(1)$ variables; and $v_{t}$ is a stochastic error term. This process eliminates asymptotically possible bias caused by endogeneity or serial correlation.

DOLS is applied to the shipping model as follows,

$$
c_{x i t}=\beta_{1}^{\prime} p_{x i t}+d(L) \Delta p_{x i t}+\beta_{2}^{\prime} z_{x i t}+d(L) \Delta z_{x i t}+\beta_{3}^{\prime} e_{i t}+d(L) \Delta e_{i t}+v_{t}
$$

substituting

$$
z_{x i t}=f_{t}
$$

or

$$
z_{x i t}=t_{x i t}
$$

where freight rate $\left(f_{t}\right)$ and actual shipping costs $\left(t_{x i t}\right)$ are the variables of interest. The model in (8a) does not count for ad-valorem charges $(g)$ when freight rate $f$ is used, based on Baltic Dry Index. As described in (6), $f$ increases with oil price $\left(o_{t-1}\right)$. 


\section{Empirical results}

The augmented Dickey-Fuller (ADF) test for the stationarity of individual variables is summarized in Table 2. The actual shipping cost variables are all stationary in log forms, whereas freight rate is difference stationary in its log form. Other integrated series are $I(1)$ series as well.

The spurious regressions are presented in Table 3. Two regressions are run for each data set: the first includes freight rate $(f)$, whereas the second includes actual shipping costs $(t)$ instead. Estimations using freight rate are cointegrated by the Engle-Granger (EG) for all four data sets, $c_{s j}^{h}, c_{s k}^{l}, c_{m j}^{l}$, and $c_{m k}^{h}$ (Table 3a). Estimations using actual shipping costs are cointegrated for three data sets $\left(c_{s j}^{h}, c_{s k}^{l}\right.$, and $\left.c_{m k}^{h}\right)$, but not cointegrated for $c_{m j}^{l}$ (Table 3b). The $\mathrm{ARCH}$ test results indicate that heteroskedasticity exists in the data, and the Breusch-Godfrey Lagrange Multiplier test results indicate the presence of autocorrelations.

[Tables 2 through 4 here]

The DOLS regression results are presented in Table 4 and discussed separately based on whether freight rate or actual shipping costs data are used following equations (8), (8a) and (8b).

(a) Regressions with freight rate

Regressions with freight rate (Baltic Dry Index) show expected results on the response of import quantity to the changes in freight rate (Table $4 a$ ). An increase in freight rate is related to an increase in U.S. imports of higher quality cars from Japan and Korea $\left(c_{s j}^{h}\right.$ and $\left.c_{m k}^{h}\right)$ and a decrease in U.S. imports of lower quality cars from Japan $\left(c_{m j}^{l}\right)$, holding car price and exchange rate constant. These results seem to support the Alchian-Allen theorem and are significant at the 
$1 \%$ level of significance. The coefficient estimate for lower quality cars from Korea $\left(c_{s k}^{l}\right)$ is not significant.

Exchange rate variable shows the expected significant negative coefficients for three data sets $\left(c_{s j}^{h}, c_{s k}^{l}\right.$, and $\left.c_{m k}^{h}\right)$ and negative but not significant coefficient for $c_{m j}^{l}$. A depreciation of the U.S. dollar increases the foreign car price and thus lowers the demand for those cars, reflected in the lower quantity of car imports.

(b) Regressions with actual shipping costs

Regressions with actual CIF charges give different results for the shipping cost variable. The significant negative coefficient of shipping cost variable for the U.S. import of higher quality cars from Korea $\left(c_{m k}^{h}\right)$ implies that an increase in shipping costs is related to a decrease in import quantity of higher quality cars, holding car price and exchange rate constant. This result counters the Alchian-Allen theorem. Similarly, the significant positive coefficient of shipping cost variable for the lower quality cars from Korea $\left(c_{s k}^{l}\right)$ shows inconsistency with Alchian-Allen theorem.

The exchange rate variable shows significant negative coefficients similar to the results from (a) for two data sets $\left(c_{s k}^{l}\right.$ and $\left.c_{m j}^{l}\right)$. However, the exchange rate variable for higher quality cars from Japan $\left(c_{s j}^{h}\right)$ has a significant positive coefficient, suggesting that a weaker U.S. dollar relative to the Japanese yen increases the import quantity of higher quality cars from Japan in the U.S. automobile market. 


\section{Conclusion}

This paper examines data on Japanese and Korean automobile exports to the United States to determine consistency with the Alchian-Allen theorem using dynamic OLS estimators. The results of this study suggest that: (1) the Alchian-Allen theorem holds when shipping costs account for per-unit freight charge only without considering insurance and other charges that may be imposed based on the car price; and (2) in the presence of insurance and other charges, Alchian-Allen theorem may hold when the effect of per-unit charge is larger than the effect of the ad-valorem charges. Hummels and Skiba (2002) report that ad-valorem trade costs such as tariffs reduce the Alchian-Allen effect. Similarly, the present study finds that insurance and other charges seem to reduce or eliminate the Alchian-Allen effect.

Estimations based on Baltic Dry shipping index as a measure of freight rate support the Alchian-Allen theorem. As shipping rates increase, U.S. imports of higher quality cars from Japan and Korea increase relative to the lower quality cars. In contrast, estimations based on actual shipping cost data (CIF charges) indicate that the relative price of higher-quality car imports is not necessarily lower when shipping costs rise. This result suggests that insurance and other charges are imposed based on the car price, and these charges reduce or eliminate the Alchian-Allen effect of per-unit freight charge. Therefore, the present shipping cost data do not support the Alchian-Allen theorem.

The model seems to work better for car imports from Korea than Japan, as indicated by the cointegration test and DOLS regression results. Two possible explanations are as follows: (1) there are more product variations in the cars imported from Japan compared to those imported from Korea, and (2) there are more trade agreements between Japan and the U.S. that may influence the types of cars imported from Japan. 
Although further study is required, the results of this study imply that foreign car production will be done domestically in the U.S. when trade costs are high, regardless differences in car quality. 


\section{References}

Alchian, Arment A. and William R. Allen. 1964. University Economics. Belmont, Wadsworth Publishing Co.

Banik, Nilanjan and Basudeb Biswas. 2007. Exchange rate pass-through in the U.S. automobile market: a cointegration approach. International Review of Economics and Finance, 16, pp. 223-236.

Bauman, Yoram. 2004. Shipping the good apples out: a new perspective. Economic Inquiry,42, pp. 534-536.

Borcherding, Thomas E. and Eugene Silberberg. 1978. Shipping the good apples out: the Alchian and Allen theorem reconsidered. The Journal of Political Economy, 95(1), pp. $131-138$.

Bureau of Economic Analysis. 2009. The U.S. National Economic Accounts. http://www.bea.gov/National/index.htm.

Bureau of Labor Statistics. 2009. Consumer Price Index - All Urban Consumers (CPI-U). http://www.bls.gov/CPI/data.htm.

FactSet Research Systems. 2010. Baltic Dry Index (BDI-BAX).

Federal Reserve Bank of New York. 2009. Foreign Exchange, Historical Data. http://www.newyorkfed.org/markets/foreignex.html.

Hummels, David and Alexandra Skiba. 2002. Shipping the good apples out? An empirical confirmation for the Alchian-Allen conjecture. NBER Working Paper, 9023.

Hummels, David and Alexandra Skiba. 2004. Shipping the good apples out? An empirical confirmation for the Alchian-Allen conjecture. Journal of Political Economy, 112(6), pp. 1384-1402.

Katzner, Donald W. and Mikail J. Nikomarov. 2008. Exercises in futility. The Japanese Economy, 35, pp. 29-58.

Kilian, Lutz. 2009. Not all price shocks are alike: distangling demand and supply shocks in the crude oil market. American Economic Review, 99(3), pp. 1053-1069.

Silberberg, Eugene and Wing Suen. 2001. The Structure of Economics: A Mathematical Analysis. ( $3^{\text {rd }}$ ed.). McGraw-Hill, New York.

Stock, James H. and Mark W. Watson. 1993. A simple estimator of cointegrating vectors in higher order integrated systems. Econometrica, 61(4), pp. 783-820. 
Tharp, Mike. 1981. U.S., Japan in car pact. New York Times, May 1, 1981, A1.

United States Department of Energy Energy Information Administration. 2009. World Crude Oil Prices. http://www.eia.doe.gov/

United States International Trade Commission. 2009-2012. Interactive Tariff and Trade Database. http://dataweb.usitc.gov/ 
Table 1. Import quantity and price data

\begin{tabular}{llcccc}
\hline & & \multicolumn{2}{c}{ Small size car import } & \multicolumn{2}{c}{ Medium size car import } \\
\cline { 3 - 6 } & & Japan & Korea & Japan & Korea \\
\hline \multirow{2}{*}{$1995 \mathrm{~m} 1-2005 \mathrm{~m} 12$} & $c_{s j}^{h}$ & $c_{s k}^{l}$ & $c_{m j}^{l}$ & $c_{m k}^{h}$ \\
\hline \multirow{2}{*}{ Import quantity } & Average & 9,122 & 6,007 & 199,235 & 30,752 \\
& Standard deviation & 5,706 & 3,644 & 64,342 & 16,582 \\
\hline \multirow{2}{*}{ Price (\$ per unit) } & Average & 11,154 & 6,916 & 8,495 & 9,646 \\
& Standard deviation & 2,050 & 653 & 1,932 & 916 \\
\hline
\end{tabular}

Note:

(1) Small size cars: Motor cars and other motor vehicles for transport of persons with spark-ignition internal combustion reciprocating piston engine of a cylinder capacity exceeding $1,000 \mathrm{cc}$ but not exceeding $1,500 \mathrm{cc}$ (HTS 8703.22).

(2) Medium size cars: Motor cars and other motor vehicles for transport of persons with spark-ignition internal combustion reciprocating piston engine of a cylinder capacity exceeding $1,500 \mathrm{cc}$ but not exceeding $3,000 \mathrm{cc}$ (HTS 8703.23).

(3) Average price is calculated by dividing total customs value by quantity of imports. The customs value is the value of imports as appraised by the U.S. Customs. This value is defined as the price actually paid or payable for merchandise, excluding U.S. import duties, freight, insurance, and other charges.

(4) Price data are deflated using Consumer Price Index - All Urban Consumers (CPI-U).

Note: i) Car import data are from the United States International Trade Commission (USITC) available on the USITC Dataweb, http://dataweb.usitc.gov/. ii) Price data are deflated by the U.S. Consumer Price Index (CPI-U) data from the Bureau of Labor Statistics, http://www.bls.gov/CPI/data.htm. 
Table 2. Augmented Dickey-Fuller (ADF) test results

\begin{tabular}{lcc}
\hline 1995m1-2005m12 & Variable & ADF test \\
\hline Import quantity & $c_{s j}^{h}$ & $-3.14^{*}$ \\
& $c_{s k}^{l}$ & -2.32 \\
& $c_{m j}^{l}$ & $-3.09^{*}$ \\
& $c_{m k}^{h}$ & -2.76 \\
\hline Car price & $p_{s j}^{h}$ & -2.12 \\
& $p_{s k}^{l}$ & -2.045 \\
& $p_{m j}^{l}$ & $-4.22^{*}$ \\
\hline Freight rate & $p_{m k}^{h}$ & -2.78 \\
\hline Actual shipping costs & $f$ & -0.50 \\
(cost, insurance and & $t_{s j}^{h}$ & $-5.85^{*}$ \\
freight) & $t_{s k}^{l}$ & $-5.12^{*}$ \\
\hline USD/KRW & $t_{m j}^{l}$ & $-5.35^{*}$ \\
\hline & $t_{m k}^{h}$ & $-5.78^{*}$ \\
\hline & $e_{j}$ & -2.25 \\
& $e_{k}$ & -1.93 \\
\hline
\end{tabular}

Note: i) ADF denotes the augmented Dickey-Fuller t-statistic with an intercept and the null hypothesis of nonstationarity. ii) Superscript * refers the case when the null hypothesis is rejected at the 5\% significance level compared to the MacKinnon critical value of 2.89. iii) Integrated series are $I(1)$ series. 
Table 3. OLS regressions and cointegration test results

(a) Regressions using freight rate

\begin{tabular}{|c|c|c|c|c|}
\hline & \multicolumn{2}{|c|}{ Small size car import } & \multicolumn{2}{|c|}{ Medium size car import } \\
\hline & Japan & Korea & Japan & Korea \\
\hline 1995m1-2005m12 & $c_{s j}^{h}$ & $c_{s k}^{l}$ & $c_{m j}^{l}$ & $c_{m k}^{h}$ \\
\hline \multirow{2}{*}{ Car price, $p_{i}$} & $0.537 *$ & $4.530 * * *$ & $-0.384 * * *$ & -0.115 \\
\hline & $(0.305)$ & $(0.856)$ & $(0.083)$ & $(0.458)$ \\
\hline \multirow{2}{*}{ Freight rate, $f$} & $0.291 *$ & $-0.865 * * *$ & $-0.616^{* * *}$ & $1.054 * * *$ \\
\hline & $(0.153)$ & $(0.222)$ & $(0.050)$ & $(0.124)$ \\
\hline \multirow{2}{*}{ Exchange rate, $e_{i}$} & $2.954 * * *$ & $3.976^{* * *}$ & $0.724 * * *$ & $-1.149 * *$ \\
\hline & $(0.422)$ & $(0.871)$ & $(0.193)$ & $(0.479)$ \\
\hline \multirow[t]{2}{*}{ Intercept } & $15.78^{* * * *}$ & $-25.33 * * *$ & $23.60^{* * *}$ & 3.398 \\
\hline & $(2.565)$ & $(7.369)$ & $(1.171)$ & $(4.221)$ \\
\hline Observation & 131 & 131 & 131 & 131 \\
\hline Adjusted $\mathrm{R}^{2}$ & 0.415 & 0.397 & 0.587 & 0.413 \\
\hline Breusch-Godfrey LM & 66.54 & 65.77 & 74.85 & 82.00 \\
\hline $\mathrm{ARCH}$ & 13.56 & 8.11 & 39.27 & 14.54 \\
\hline $\begin{array}{l}\text { Engle-Granger test } \\
\mathrm{EG}_{\tau}=-3.8\end{array}$ & -4.62 & -4.42 & -4.21 & -3.93 \\
\hline
\end{tabular}

(b) Regressions using actual shipping cost (cost, insurance, and freight)

\begin{tabular}{|c|c|c|c|c|}
\hline & \multicolumn{2}{|c|}{ Small size car import } & \multicolumn{2}{|c|}{ Medium size car import } \\
\hline & Japan & Korea & Japan & Korea \\
\hline 1995m1-2005m12 & $c_{s j}^{h}$ & $c_{s k}^{l}$ & $c_{m j}^{l}$ & $c_{m k}^{h}$ \\
\hline \multirow{2}{*}{ Car price, $p_{i}$} & $1.013 * * *$ & $5.884 * * *$ & -0.208 & 0.277 \\
\hline & $(0.258)$ & $(1.095)$ & $(0.191)$ & $(0.435)$ \\
\hline \multirow{2}{*}{ Shipping costs, $t_{i}$} & 0.142 & $-1.527 * * *$ & $-0.278^{*}$ & $-1.735^{* * *}$ \\
\hline & $(0.179)$ & $(0.484)$ & $(0.146)$ & $(0.251)$ \\
\hline \multirow[t]{2}{*}{ Exchange rate, $e_{i}$} & $3.374 * * *$ & -0.703 & 0.248 & $-1.946 * * *$ \\
\hline & $(0.389)$ & $(0.630)$ & $(0.282)$ & $(0.226)$ \\
\hline \multirow{2}{*}{ Intercept } & $14.713 * * *$ & $-39.95 * * *$ & $16.66^{* * *}$ & 4.182 \\
\hline & (3.584) & $(14.05)$ & (1.499) & $(4.323)$ \\
\hline Observation & 132 & 132 & 132 & 132 \\
\hline Adjusted $\mathrm{R}^{2}$ & 0.399 & 0.272 & 0.057 & 0.463 \\
\hline Breusch-Godfrey LM & 69.21 & 55.19 & 104.88 & 55.19 \\
\hline $\mathrm{ARCH}$ & 20.47 & 7.63 & 77.38 & 7.630 \\
\hline $\begin{array}{l}\text { Engle-Granger test } \\
\mathrm{EG}_{\tau}=-3.8\end{array}$ & -4.45 & -4.02 & -2.94 & -5.44 \\
\hline $\begin{array}{l}* * *, * *, * \text { indicate that } \\
\text { parentheses. Actual sh } \\
\text { freight) value, and the } r \\
\text { USITC ( } 2010) \text { as "the } p \\
\text { insurance, and other ch }\end{array}$ & $\begin{array}{l}\text { ficient is } s \\
\text { ost is calcu } \\
\text { divided by } \\
\text { ually paid }\end{array}$ & $\begin{array}{l}\text { at } 1 \%, 5 \% \text {, a } \\
\text { educting the } \\
\text { uantity of ca } \\
\text { for merchan } \\
\text { des U.S. imp }\end{array}$ & $\begin{array}{l}\text { l, respectiv } \\
\text { lue from th } \\
\text { The custom } \\
\text { ling U.S. in }\end{array}$ & $\begin{array}{l}\text { derrors are in } \\
\text { nsurance, an } \\
\text { fined by the } \\
\text { freight, }\end{array}$ \\
\hline
\end{tabular}


Table 4. Stock-Watson dynamic OLS regression results

(a) Regressions using freight rate

\begin{tabular}{|c|c|c|c|c|}
\hline & \multicolumn{2}{|c|}{ Small size car import } & \multicolumn{2}{|c|}{ Medium size car import } \\
\hline & Japan & Korea & Japan & Korea \\
\hline $1995 \mathrm{~m} 1-2005 \mathrm{~m} 12$ & $c_{s j}^{h}$ & $c_{s k}^{l}$ & $c_{m j}^{l}$ & $c_{m k}^{h}$ \\
\hline Car price, $p_{i}$ & $-3.021 * * *$ & $4.97 * * *$ & $-0.486 * * *$ & $-1.916^{*}$ \\
\hline & $(0.951)$ & $(1.480)$ & $(0.062)$ & $(0.962)$ \\
\hline Freight rate, $f$ & $\begin{array}{c}2.676^{* * *} * \\
(0.603)\end{array}$ & $\begin{array}{l}-0.278 \\
(0.421)\end{array}$ & $\begin{array}{c}-1.122 * * * \\
(0.083)\end{array}$ & $\begin{array}{c}2.628 * * * \\
(0.378)\end{array}$ \\
\hline Exchange rate, $e_{i}$ & $\begin{array}{c}-4.395 * * \\
(1.824)\end{array}$ & $\begin{array}{c}-5.635^{* * *} \\
(2.602)\end{array}$ & $\begin{array}{l}-0.288 \\
(0.717)\end{array}$ & $\begin{array}{c}-5.381 * * * \\
(1.357)\end{array}$ \\
\hline Intercept & $\begin{array}{l}-3.931 \\
(10.05)\end{array}$ & $\begin{array}{c}-33.16^{* * *} \\
(11.01)\end{array}$ & $\begin{array}{c}23.37 * * * \\
(3.566)\end{array}$ & $\begin{array}{c}8.545 \\
(7.326)\end{array}$ \\
\hline F value & 63.91 & 64.53 & 813.3 & 66.83 \\
\hline Prob $>F$ & 0.000 & 0.000 & 0.000 & 0.000 \\
\hline
\end{tabular}

$* * *, * * *$ indicate that the coefficient is significant at $1 \%, 5 \%$, and $10 \%$ level, respectively; Newey-West standard errors are in parentheses. Freight rate is based on Baltic Dry Index as an increasing function of oil price (with a onemonth lag).

(b) Regressions using actual shipping cost (cost, insurance, and freight)

\begin{tabular}{|c|c|c|c|c|}
\hline & \multicolumn{2}{|c|}{ Small size car import } & \multicolumn{2}{|c|}{ Medium size car import } \\
\hline & Japan & Korea & Japan & Korea \\
\hline $1995 \mathrm{~m} 1-2005 \mathrm{~m} 12$ & $c_{s j}^{h}$ & $c_{s k}^{l}$ & $c_{m j}^{l}$ & $c_{m k}^{h}$ \\
\hline \multirow{2}{*}{ Car price, $p_{i}$} & 0.774 & $4.940 * * *$ & -0.167 & $1.591^{*}$ \\
\hline & $(0.487)$ & $(1.100)$ & $(0.245)$ & $(0.832)$ \\
\hline \multirow[t]{2}{*}{ Shipping costs, $t_{i}$} & 0.061 & $1.122 * *$ & $-0.445^{* *}$ & $-1.750 * * *$ \\
\hline & $(0.248)$ & $(0.490)$ & $(0.217)$ & $(0.642)$ \\
\hline \multirow[t]{2}{*}{ Exchange rate, $e_{i}$} & $4.753 * * *$ & $-12.97 * * *$ & $-1.172 * *$ & -1.868 \\
\hline & $(0.975)$ & $(3.415)$ & $(0.476)$ & $(2.730)$ \\
\hline \multirow{2}{*}{ Intercept } & $23.859 * * *$ & $-41.19 * * *$ & $10.42 * * *$ & 5.897 \\
\hline & $(7.878)$ & $(9.566)$ & $(2.776)$ & $(8.293)$ \\
\hline F value & 4.03 & 34.18 & 15.68 & 3.46 \\
\hline Prob $>$ F & 0.000 & 0.000 & 0.000 & 0.000 \\
\hline
\end{tabular}

